foi utilizado Biodentine ${ }^{\circledR}$ como material de reparação do defeito de reabsorção.

Discussão e conclusões: A reabsorção radicular externa é um processo multifatorial com diversos fatores etiológicos. $\mathrm{O}$ CBCT é essencial no diagnóstico e plano de tratamento deste tipo de lesões. Após a realização do controlo após um ano verificou-se a reparação da reabsorção radicular e cicatrização progressiva do defeito ósseo.

http://doi.org/10.24873/j.rpemd.2017.12.069

\section{\#040 Eritema Multiforme Major oral associado a toma de Ácido Valproico}

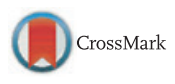

Marcelo Prates*, Patrícia Caixeirinho, Afonso Simões Martins, Luísa Figueiredo, Maria João Costa, Francisco Proença

Centro Hospitalar Lisboa Central - Hospital São José

Introdução: O eritema multiforme é uma afeção aguda, autolimitada e por vezes recorrente da pele e mucosas, com largo espectro de apresentações ou severidade e que se pensa ter origem numa reação de hipersensibilidade tipo IV associada na maior parte dos casos a infeções ou a medicação. $\mathrm{Na}$ forma major tipicamente com lesões em alvo e pápulas edematosas com distribuição acral e envolvimento de uma ou mais mucosas.

Descrição do caso clínico: Homem, 24 anos, raça negra, com Hepatite B e história de abuso de canabinóides, internado por ideação delirante persecutória e alucinações auditivas. Após avaliação foi medicado com olanzapina, haloperidol e ácido válproico. 16 dias depois inicia quadro de mialgias generalizadas e ulcerações a nível dos lábios, mucosa jugal e gengival. Com sinais de hemorragia recente. Língua e pavimento oral poupados. Com áreas de necrose justa comissura labial bilateralmente, descamativas e ligeiramente exsudativas. Lesões com dor local permanente e estomatorragia. Parou ácido válproico e iniciou prednisolona e antibioterapia com amoxicilina e metronidazol por supuração secundária. Fez reforço da hidratação oral e da higiene oral com clorohexidina. 4 dias depois com melhoria das lesões mantendo dor e estomatorragia raras. Iniciou remoção de tecidos destacáveis com compressa embebida em soro e aplicação de gel de ácido hialurónico nas lesões intraorais e vaselina nos lábios. Parou corticoterapia sistémica por potencial descompensação da patologia de base, iniciando betametasona tópica. Fez antibioterapia durante 14 dias com melhoria quase completa das lesões mantendo hidratação e higiene. 18 dias após início do quadro já sem qualquer lesão da mucosa oral ou lábios.

Discussão e conclusões: Apresentamos um caso de eritema multiforme major com sobreinfeção bacteriana em doente com Hepatite B e consumo de canabinóides como fatores de risco. Visto que mais de $50 \%$ dos casos são relacionados com medicamentos admitiu-se como trigger o início recente de ácido valpróico, uma das drogas mais envolvidas nesta situação. Frequentemente só é necessária terapêutica sintomática e suspensão/controlo da causa mas alguns doentes podem necessitar de internamento para hidratação, analgesia, terapia antiviral, corticoterapia sistémica ou antibioterapia. O eritema multiforme pode apresentar-se com lesões da mucosa oral antes de evoluir para uma forma mais severa pelo que um alto nível de suspeição é fundamental para evitar o atraso no diagnóstico.

http://doi.org/10.24873/j.rpemd.2017.12.070

\section{\#041 Gengivite Ulcerativa Necrotizante: A propósito de um caso clínico}

Pedro Cabeça Santos*, Juliana Medeiros Almeida, Pedro Alberto Santos, Catarina Fraga, Tiago Fonseca, João Correia Pinto

\section{Centro Hospitalar de São João, E.P.E. - Hospital de São João}

Introdução: A gengivite ulcerativa necrotizante trata-se de uma doença periodontal aguda, causada por infeção gengival bacteriana. Esta entidade é caracterizada pela necrose dos tecidos moles gengivais e pode progredir para a destruição da estrutura periodontal em todos os seus componentes, com consequente perda de inserção dos mesmos. É mais frequente em adultos jovens, sem predomínio de género. Estão identificados vários fatores de risco locais e sistémicos, nomeadamente: a insuficiente higiene oral, o tabagismo, a imunossupressão, a má-nutrição severa e as perturbações psico-emocionais. O diagnóstico é clínico, pela tríade de dor e hemorragia gengivais com necrose papilar associada e eventual envolvimento sistémico. O tratamento passa pelo desbridamento do tecido necrótico, reforço da higiene oral com colutório de clorexidina a 0,12\%, analgesia e, em caso de resposta sistémica, antibioterapia.

Descrição: Mulher, 62 anos de idade, fumadora de 42 unidades maço/ano, sem antecedentes patológicos relevantes, medicada cronicamente com alprazolam e paroxetina. Recorreu ao serviço de urgência por dor no $5 .^{\circ}$ sextante, com 3 dias de evolução e agravamento progressivo e febre nas últimas $24 \mathrm{~h}$. Sem outros sintomas de relevo ou agravamento da sua patologia psiquiátrica. Objetivou-se estado subfebril $\left(37,6^{\circ} \mathrm{C}\right.$ auricular), parca higiene oral, hálito fétido, gengiva do $5 .^{\circ}$ sextante com sinais inflamatórios, com necrose papilar e hemorragia à sondagem periodontal, sem mobilidade dentária ou exposição radicular. Assumindo-se o diagnóstico de gengivite ulcerativa necrosante, aconselhou-se a utente a suspender os hábitos tabágicos e melhorar os cuidados de higiene oral. Instituiu-se terapêutica com amoxicilina/ácido clavulânico, metronidazol, bochechos de clorexidina a 0,12\%, ibuprofeno e paracetamol. A utente foi encaminhada para consulta de Estomatologia, que decorreu 7 dias depois. Apresentava franca melhoria do quadro clínico e da higiene oral, procedendo-se a tartarectomia. Atualmente encontra-se em vigilância clínica.

Discussão e conclusões: A gengivite ulcerativa necrosante é uma doença periodontal aguda grave, podendo evoluir para doença crónica. Este caso permite evidenciar o caráter clínico do diagnóstico e apresenta-se como grave, pois é foco de sépsis. O tratamento mecânico deverá ser instituído precocemente, de maneira a evitar recorrência ou progressão da doença.

http://doi.org/10.24873/j.rpemd.2017.12.071 